\title{
Influence of decavanadate on rat synaptic plasma membrane ATPases activity
}

\author{
Danijela Krstić ${ }^{\text {, Mirjana Čolović }}{ }^{2}$, Nada Bošnjaković-Pavlović ${ }^{3}$, Anne Spasojević-De Bire ${ }^{4}$ \\ and VesnaVasić ${ }^{2}$ \\ ${ }^{1}$ Institute of Medicinal Chemistry, University School of Medicine, Belgrade, Serbia \\ ${ }^{2}$ Department of Physical Chemistry, Vinča Institute of Nuclear Sciences, Belgrade, Serbia \\ ${ }^{3}$ Faculty of Physical Chemistry, University of Belgrade, Serbia \\ ${ }^{4}$ Ecole Centrale Paris, Laboratoire SPMS UMR CNRS 85801, Grande Voie des Vignes, 92295 Châtenay-Malabry, France
}

\begin{abstract}
The in vitro influence of decameric vanadate species on $\mathrm{Na}^{+} / \mathrm{K}^{+}$-ATPase, plasma membrane $\mathrm{Ca}^{2+}$-ATPase (PMCA)-calcium pump and ecto-ATPase activity, using rat synaptic plasma membrane (SPM) as model system was investigated, whereas the commercial porcine cerebral cortex $\mathrm{Na}^{+} / \mathrm{K}^{+}$-ATPase served as a reference. The thermal behaviour of the synthesized decavanadate $\left(\mathrm{V}_{10}\right)$ has been studied by differential scanning calorimetry and thermogravimetric analysis, while the type of polyvanadate anion was identified using the IR spectroscopy. The concentration-dependent responses to $\mathrm{V}_{10}$ of all enzymes were obtained. The half-maximum inhibitory concentration $\left(\mathrm{IC}_{50}\right)$ of the enzyme activity was achieved at $(4.74 \pm 1.15) \times 10^{-7} \mathrm{~mol} / \mathrm{l}$ for SPM Na${ }^{+} / \mathrm{K}^{+}$-ATPase, $(1.30$ $\pm 0.10) \times 10^{-6} \mathrm{~mol} / \mathrm{l}$ for commercial $\mathrm{Na}^{+} / \mathrm{K}^{+}$-ATPase and $(3.13 \pm 1.70) \times 10^{-8} \mathrm{~mol} / \mathrm{l}$ for Ca ${ }^{2+}$-ATPase, while ecto-ATPase is significantly less sensitive toward $\mathrm{V}_{10}\left(\mathrm{IC}_{50}=(1.05 \pm 0.10) \times 10^{-4} \mathrm{~mol} / \mathrm{l}\right)$ than investigated P-type ATPases. Kinetic analysis showed that $\mathrm{V}_{10}$ inhibited $\mathrm{Na}^{+} / \mathrm{K}^{+}$-ATPase by reducing the maximum enzymatic velocity and apparent affinity for ATP (increasing $\mathrm{K}_{\mathrm{m}}$ value), implying a mixed mode of interaction between $\mathrm{V}_{10}$ and P-type ATPases.
\end{abstract}

Key words: Decavanadate $-\mathrm{Na}^{+} / \mathrm{K}^{+}$-ATPase - Plasma membrane $\mathrm{Ca}^{2+}$-ATPase - ecto-ATPase

\section{Introduction}

Interest in the interaction of vanadate oxoanions with biological systems has increased since it has been demonstrated to have a variety of physiological effects acting either as a phosphate analogue in the monomeric form $\left(\mathrm{H}_{2} \mathrm{VO}_{4}{ }^{-}\right)$(Cantley et al. 1977) or through oligomeric (dimeric, tetrameric and decameric) vanadate species which interact with many biomolecules with various and versatile activity (enzymes inhibitor or activator). Recent data indicate spermicidal and anti-HIV activity of vanadium compounds (D'Cruz et al. 2003) and the use of these compounds for the treatment of diabetes (Heinemann et al. 2003; Sakurai et al. 2004; Yang et al. 2004) as well as the prevention of animal carcinogens

Correspondence to: Danijela Krstić, Institute of Medicinal Chemistry, University School of Medicine, Višegradska 26, 11000 Belgrade, Serbia

E-mail: krsticdana@yahoo.com
(Kanna et al. 2004; Molinuevo et al. 2004). It was reported that decavanadate $\left(\mathrm{V}_{10}\right)$ is the major protein-bound species of vanadium and have a stronger effect on various enzymes, when compared to other vanadate oligomers (Aureliano and Gândara 2005). Recently reported $V_{10}$ studies include the possibility of its use as a tool in the understanding of the transducing chemical energy into conformational energy for $\mathrm{Ca}^{2+}$ transport by $\mathrm{Ca}^{2+}$-ATPase (Stokes et al. 2005) as well as molecular mechanism of muscle contraction (Tiago et al. 2004). Inhibitions of several adenosine triphosphatases (ATPases) such as P-type ATPases, ABC-ATPases and ribonucleases by $\mathrm{V}_{10}$ suggest that $\mathrm{V}_{10}$ interactions with these proteins probably favored by the existence of an ATP binding site (Messmore and Raines 2000; Pezza et al. 2002).

$\mathrm{Na}^{+} / \mathrm{K}^{+}$-ATPase (sodium pump) and plasma membrane $\mathrm{Ca}^{2+}$-ATPase (PMCA)-calcium pump belong to the P-type ATPase family, the members of which are able to utilize the energy of ATP to transport ions against their electrochemical gradient across membrane and strongly inhibited by 
nanomolar concentration of orthovanadate (Cantley et al. 1977).

$\mathrm{Na}^{+} / \mathrm{K}^{+}$-ATPase is a cell membrane located enzyme that establishes and maintains the high internal $\mathrm{K}^{+}$and low internal $\mathrm{Na}^{+}$concentrations, characteristic and essential for normal cellular activities of most animal cells (Vasilets and Schwarz 1993; Rodriguez de Lores Arnaiz and Pena 1995). The activity of this enzyme is very sensitive to the presence of some metal ions and organic compounds of various structures, especially some drugs and pesticides (Blasiak 1995; Krstić et al. 2004, 2005). PMCA is a fine tuner of cytosolic calcium concentration in excitable cells, while the calcium pump is the sole system responsible for extrusion of calcium ions outside nonexcitable cells (Zylinska and Soszynski 2000). The ecto-ATPase, which does not belong to the P-type ATPase family, represents an integral membrane protein that, in the presence of divalent cations $\left(\mathrm{Ca}^{2+}\right.$ or $\left.\mathrm{Mg}^{2+}\right)$, hydrolyses extracellular nucleotides because of the outward orientation of its active site (Nagy 1986). By hydrolysing ATP to ADP, ecto-ATPase represents the major inactivating agent in purine-triphosphate signalling (Horvat et al. 2006). The aim of this work was the investigation of the in vitro effect of ammonium $\mathrm{V}_{10},\left(\mathrm{NH}_{4}\right)_{6} \mathrm{~V}_{10} \mathrm{O}_{28} \cdot 5 \mathrm{H}_{2} \mathrm{O}$ on $\mathrm{Na}^{+} / \mathrm{K}^{+}$-ATPase (sodium pump), PMCA-calcium pump and ecto-ATPase $\left(\mathrm{Mg}^{2+}\right.$. ATPase) activity, using rat synaptic plasma membrane (SPM) as a model system, while the commercial porcine cerebral cortex $\mathrm{Na}^{+} / \mathrm{K}^{+}$-ATPase served as a reference. In addition, extensive kinetic studies of porcine cerebral cortex $\mathrm{Na}^{+} / \mathrm{K}^{+}$-ATPase were undertaken to determine the nature of enzyme inhibition by $\mathrm{V}_{10}$. These enzymes were chosen because of their key role in normal functioning most cells of higher eukaryotic organisms (Scheiner-Bobis 2002) as well as pivotal roles in cancer cell migration (Lefranc et al. 2008) and, on the other hand, known influence of $V_{10}$ on nucleotide-dependent enzymes (Boyd et al. 1985; Csermely et al. 1985; Varga et al. 1985; Aureliano 2000; Pezza et al. 2002; Aureliano and Gândara 2005).

\section{Materials and Methods}

\section{Chemicals}

All chemicals were of analytical grade. $\mathrm{Na}^{+} / \mathrm{K}^{+}$-ATPase from porcine cerebral cortex and ATP were purchased from Sigma Co., as well as some chemicals for medium assay (magnesium chloride and Tris- $\mathrm{HCl}$ ). The specific $\mathrm{Na}^{+} / \mathrm{K}^{+}$-ATPase activity was $25.8 \mu \mathrm{mol} \mathrm{Pi} / \mathrm{h} / \mathrm{mg}$ protein ( $\mathrm{Pi}$ - inorganic orthophosphate). Other medium assay chemicals (sodium chloride, potassium chloride), chemicals for determination of $\mathrm{Pi}$ (stannous chloride and ammonium molybdate) and ammonium trioxovanadate
$\left(\mathrm{NH}_{4} \mathrm{VO}_{3}\right)$ used for synthesis were from Merck (Darmstadt, Germany).

\section{Synthesis of ammonium $V_{10}$}

The title compound, $\left(\mathrm{NH}_{4}\right)_{6} \mathrm{~V}_{10} \mathrm{O}_{28} \cdot 5 \mathrm{H}_{2} \mathrm{O}$, was prepared by dissolving $\mathrm{NH}_{4} \mathrm{VO}_{3}(0.4 \mathrm{~g}, 3.42 \mathrm{mmol})$ in distilled water $(20 \mathrm{ml})$ as described in Chinea et al. (2000) to obtain $\mathrm{V}_{10}$ anions. The solution was stirred and heated until complete dissolution of $\mathrm{NH}_{4} \mathrm{VO}_{3}$ (about $2 \mathrm{~h}$ ). The $\mathrm{pH}$ was adjusted to 5.90 by dropwise addition of $\mathrm{NH}_{4} \mathrm{OH}$. Orange crystals were formed within four days from the solution, kept at room temperature.

\section{Thermal studies}

Thermal analysis was performed on Instruments model SDT 2960 Simultaneous DSC-TGA (differential scanning calorimetry-thermogravimetric analysis) under following conditions: air atmosphere, sample mass $100 \mathrm{mg}$, heating rate $10^{\circ} \mathrm{C} \cdot \mathrm{min}^{-1}$, temperature interval $20-700^{\circ} \mathrm{C}$.

\section{Infrared (IR) spectroscopy}

The IR spectra in pastille was recording on Thermo Scientific spectrometer Nicolet 6700FT-IC, at room temperature, in the range $450-4000 \mathrm{~cm}^{-1}$. The solid compound was mixed with potassium bromide into transparent disk.

\section{Preparation of $V_{10}$ solution}

Ammonium $\mathrm{V}_{10}$ stock solution $(10 \mathrm{mmol} / \mathrm{l})$ was prepared by diluting $117.3 \mathrm{mg}$ of $\mathrm{V}_{10}$ in $10 \mathrm{ml}$ of water and held in refrigerator until use. Working solutions were prepared daily by diluting stock solution to desired concentrations.

\section{SPM preparation}

SPM were isolated from the whole brain of 3-month-old male Wistar albino rats from the local colony. Animals were kept under controlled illumination (lights on: 5:00 a.m.- 5:00 p.m.) and temperature $\left(23 \pm 2{ }^{\circ} \mathrm{C}\right)$, and had free access to food and water. The Guiding Principles for the Care and Use of Animals based upon Helsinki Declaration (1964) and Protocol of the "Vinča" Institute on Care and Treatment of Laboratory Animals were strictly followed. After decapitation with a guillotine (Harvard Apparatus), brains were rapidly excised and pooled (6/pool) for immediate preparation of SPM isolated according to the method of Cohen et al. (1977), as modified by Towle and Sze (1983). The mitochondrial contamination and protein content were determined according to the standard procedure (Nikezić et al. 1998.) SPM were stored at $-70^{\circ} \mathrm{C}$ until used. 


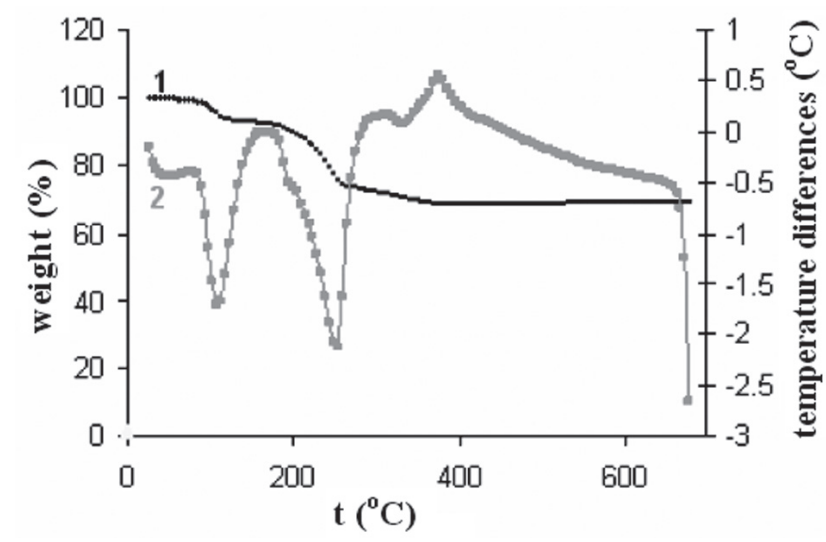

Figure 1. Thermogravimetric analysis (line 1) and differential scanning calorimetry (line 2) curves for the thermal decomposition of compound $\left(\mathrm{NH}_{4}\right)_{6} \mathrm{~V}_{10} \mathrm{O}_{28} \cdot 5 \mathrm{H}_{2} \mathrm{O}$.

\section{ATPase assays}

The standard assay medium for investigation of $\mathrm{Na}^{+} / \mathrm{K}^{+}$-ATPase activity contained (in $\mathrm{mmol} / \mathrm{l}$ ): 50 Tris- $\mathrm{HCl}$ ( $\mathrm{pH} 7.4$ ), $100 \mathrm{NaCl}, 20 \mathrm{KCl}, 5 \mathrm{MgCl}_{2}, 2 \mathrm{ATP}$ and $125 \mathrm{mg} / \mathrm{SPM}$ proteins (i.e. $290 \mathrm{mg} / \mathrm{l}$ commercial porcine cerebral cortex proteins) while the rat synaptic PMCA activity was assayed in standard medium containing (in mmol/l): 50 Tris- $\mathrm{HCl}$ ( $\mathrm{pH}$ 7.4), 0.5 EGTA, $0.5 \mathrm{CaCl}_{2}, 5 \mathrm{MgCl}_{2}, 2$ ATP and 125 $\mathrm{mg} / \mathrm{l} \mathrm{SPM}$ proteins in a final volume of $200 \mu \mathrm{l}$. Assay for SPM ecto-ATPase activity contained (in mmol/l): 50 Tris- $\mathrm{HCl}$ ( $\mathrm{pH} 7.4$ ), $5 \mathrm{MgCl}_{2}, 2 \mathrm{ATP}$ and $125 \mathrm{mg} / \mathrm{l} \mathrm{SPM}$ proteins. After preincubation for $10 \mathrm{~min}$ at $37^{\circ} \mathrm{C}$ in the absence (control) or in the presence of investigated compound, the reaction was initiated by addition of ATP and stopped after $10 \mathrm{~min}$ by adding $22 \mu \mathrm{l}$ ice cold of $3 \mathrm{~mol} / \mathrm{l} \mathrm{HClO}_{4}$ and immediate cooling on ice. The released $\mathrm{Pi}$ liberated from the hydrolysis of ATP was determined by a modified spectrophotometric method (Vasić et al. 1999). The spectrophotometric measurements were performed on a Perkin Elmer Lambda 35 UV VIS spectrophotometer. The activity obtained in the presence of $\mathrm{Mg}^{2+}$ alone was attributed to ecto-ATPase activity. SPM $\mathrm{Na}^{+} / \mathrm{K}^{+}$-ATPase as well as SPM Ca ${ }^{2+}$-ATPase activities were calculated by subtracting the $\mathrm{Mg}^{2+}$-ATPase (ecto-ATPase) activity from the total ATPase activity in the presence of $\mathrm{Na}^{+}, \mathrm{K}^{+}$and $\mathrm{Mg}^{2+}$ ions (i.e. in the presence of $\mathrm{Ca}^{2+}$ and $\mathrm{Mg}^{2+}$ ions). The results are expressed as mean percentage enzyme activity compared to the corresponding control value \pm S.E.M. of at least three independent experiments done in triplicate.

\section{Kinetic analysis}

Kinetic experiments were carried out according to the slightly modified method of Philips (Philips et al. 1978) using the commercial porcine cerebral cortex $\mathrm{Na}^{+} / \mathrm{K}^{+}$ATPase. The initial velocities were measured in the same incubation medium as a function of rising concentrations of $\mathrm{MgATP}^{2-}$ (0.1-5.0 mmol/l). The measurements were performed in the absence and presence of $\mathrm{V}_{10}$, while maintaining the concentrations of other ions $\left(\mathrm{Na}^{+}, \mathrm{K}^{+}\right.$ and $\mathrm{Mg}^{2+}$ ) constant. The experimental data were fitted to the Michaelis-Menten equation by nonlinear regression analysis using EZ-FIT program (Perrella 1988). Maximum enzymatic velocity $\left(\mathrm{V}_{\max }\right)$ and Michaelis constant $\left(\mathrm{K}_{\mathrm{m}}\right)$ values were derived by nonlinear regression fitting (hyperbola function) of the experimental data as well as from a Lineweaver-Burk plot and expressed in $\mu \mathrm{mol}$ $\mathrm{Pi} / \mathrm{h} / \mathrm{mg}$ protein and $\mathrm{mmol} / \mathrm{l}$ of ATP. Results are given as means \pm S.E.M.

\section{Results}

\section{Thermal studies}

Thermal decomposition of ammonium $\mathrm{V}_{10}$ starts at $85^{\circ} \mathrm{C}$, and proceeds as a more step process (Fig. 1). All endo- and exothermic effects are connected with weight changes. The first endothermic step corresponds to the loss of the crystallization water molecules $\left(85-155^{\circ} \mathrm{C}\right)$. This crystal form is stable up to $175^{\circ} \mathrm{C}$. This step corresponds to the weight loss about $8 \%$ and to the departure of about five water molecules per $\mathrm{V}_{10}$. After this temperature, there are an endothermic step $\left(180-300^{\circ} \mathrm{C}\right)$ and another exothermic step $\left(330-400^{\circ} \mathrm{C}\right)$. They correspond to exothermic processes arising from the combustion of organic groups. At about $400^{\circ} \mathrm{C}$, the thermostable form, $\mathrm{V}_{2} \mathrm{O}_{5}$, was formed. Thermogravimetric analysis curves show that the synthesized $\mathrm{V}_{10}$ contains 5 molecules of water at room temperature.

\section{IR spectra}

The IR spectroscopy is a good method of identification of the type of polyvanadate anion as the structures of these anions are relatively rigid. They are only slightly influenced by the nature of cation and by hydrogen bonds between cation and anion or between crystal water and anion, respectively. Therefore, the synthesized compound could be identified based on their IR spectra (Fig. 2).

The IR spectra of the synthesized $\mathrm{V}_{10}$ contains the bands which are characteristic for the groups: $\mathrm{NH}_{4}{ }^{+}, \mathrm{OH}^{-}$and $\mathrm{V}-\mathrm{O}$. The characteristic bands for $\mathrm{NH}_{4}{ }^{+}$is at $1400 \mathrm{~cm}^{-1}$, bending, and for $\mathrm{OH}^{-}$at about $1607 \mathrm{~cm}^{-1}$. In the $450-1000 \mathrm{~cm}^{-1}$ region the IR spectra of the $\mathrm{V}_{10}$ exhibits bands corresponding to $\mathrm{V}$-Ot stretching at $950 \mathrm{~cm}^{-1}$ and to $\mathrm{V}$-Ob stretching at $809 \mathrm{~cm}^{-1}$, all of them with position characteristic for $\mathrm{V}_{10}$ (Escobar and Baran 1981). 
The in vitro influence of $V_{10}$ on SPM ATPase activity

The influence of $\mathrm{V}_{10}$ on SPM ATPases and commercial porcine cerebral cortex $\mathrm{Na}^{+} / \mathrm{K}^{+}$-ATPase activity was investigated by in vitro exposure to the enzymes in the concentration range from $1 \times 10^{-10}$ to $1 \times 10^{-3} \mathrm{~mol} / \mathrm{l}$. The results show that increasing concentrations of $\mathrm{V}_{10}$ induce inhibition of enzymatic activity in a concentration-dependent manner in all cases (Fig. 3a). The dependence of enzyme activity, expressed as a percentage of the control value (obtained without inhibitor), on inhibitor concentration fits a sigmoidal function (Eq. (1)) for all enzymes. The half-maximum inhibitory concentrations $\left(\mathrm{IC}_{50}\right)$ of the investigated compound for all ATPases were determined by sigmoidal fitting the experimental results as well as by Hill analysis (Eq. (2); Fig. 3b) and are summarized in Table 1.

$$
y=\frac{A_{1}-A_{2}}{1+\left(x / x_{0}\right)^{p}}+A_{2}
$$

where $A_{1}$ and $A_{2}$ are constant parameters $\left(A_{1} \approx 100, A_{2} \approx 0\right)$, $x$ is $\mathrm{V}_{10}$ concentration in mol/l, $x_{0}$ is equal to $\mathrm{IC}_{50}$ value and $y$ is enzyme activity (percentage of control).

$$
\log \left(\frac{\% \text { activity }}{100-\% \text { activity }}\right)=-n \log [I]+n \log \mathrm{IC}_{50}
$$

where $n$ is Hill's coefficient and $[I]$ is inhibitor $\left(\mathrm{V}_{10}\right)$ concentration.

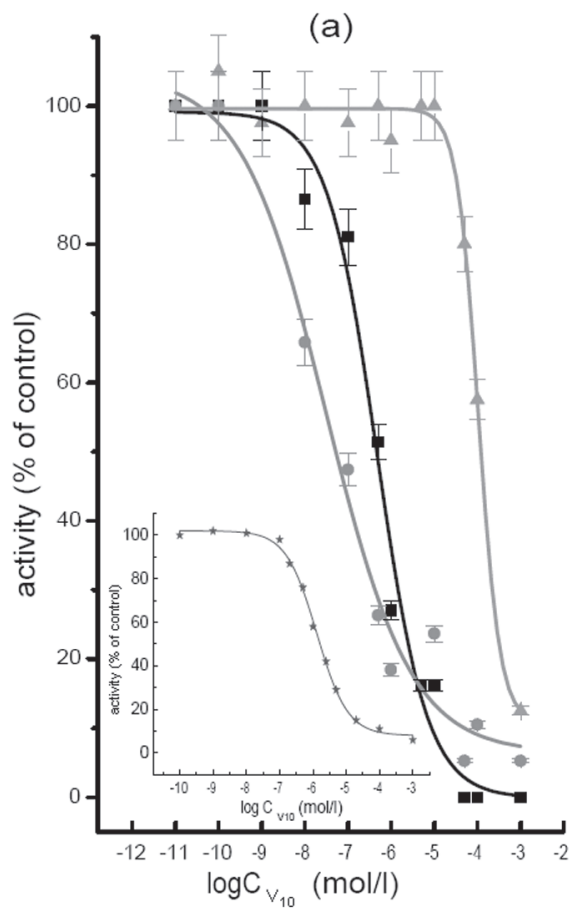

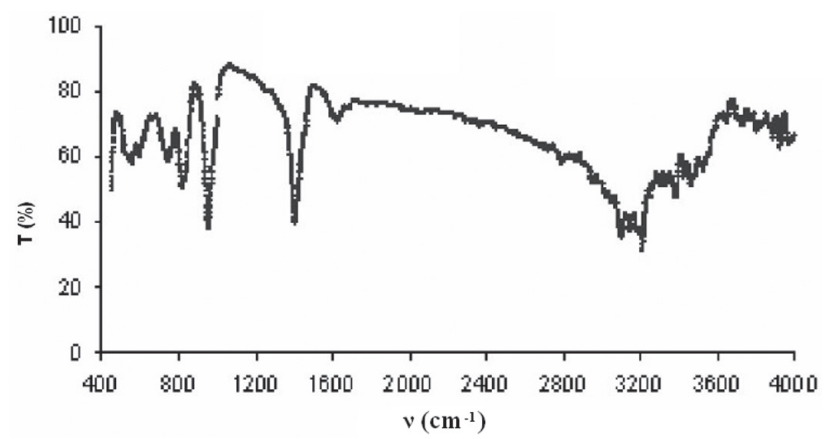

Figure 2. IR spectra (tansmittance $(\mathrm{T})$ dependence on vawenumber $(v))$ of $\left(\mathrm{NH}_{4}\right)_{6} \mathrm{~V}_{10} \mathrm{O}_{28} \cdot 5 \mathrm{H}_{2} \mathrm{O}$ recorded at room temperature.

All the parameters of both used equations are reported in Table 1. It is clearly apparent that plasma membrane calcium and sodium pumps (SPM ATPases and commercial porcine cerebral cortex) are more sensitive toward $\mathrm{V}_{10}$ anion than ecto-ATPase. At the concentration of $1 \times 10^{-5} \mathrm{~mol} / 1 \mathrm{~V}_{10}$ inhibits both SPM and commercial $\mathrm{Na}^{+} / \mathrm{K}^{+}$-ATPase as well as $\mathrm{Ca}^{2+}$-ATPase up to $80 \%$, while the effect of the same concentration of $\mathrm{V}_{10}$ on the ecto-ATPase activity is negligible. $\mathrm{IC}_{50}$ of the enzyme activity is achieved at $(4.74 \pm 1.15) \times 10^{-7}$ $\mathrm{mol} / \mathrm{l}$ for SPM Na${ }^{+} / \mathrm{K}^{+}$-ATPase, $(1.30 \pm 0.10) \times 10^{-6} \mathrm{~mol} / \mathrm{l}$ for commercial $\mathrm{Na}^{+} / \mathrm{K}^{+}$-ATPase and $(3.13 \pm 1.70) \times 10^{-8} \mathrm{~mol} / \mathrm{l}$ for $\mathrm{Ca}^{2+}$-ATPase, while the same effect for ecto-ATPase is

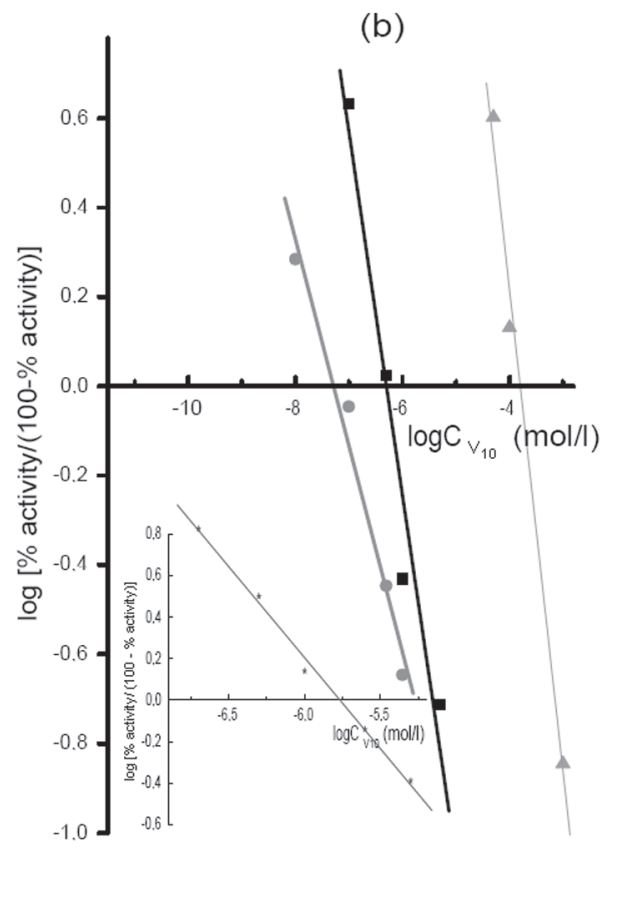

Figure 3. The concentration dependent (a) and Hill analysis (b) inhibition of SPM Na ${ }^{+} / \mathrm{K}^{+}$-ATPase (square), $\mathrm{Ca}^{2+}$-ATPase (circle), $\mathrm{Mg}^{2+}$-ATPase (triangle) and commercial porcine cerebral cortex $\mathrm{Na}^{+} / \mathrm{K}^{+}$-ATPase (inset) by ammonium decavanadate $\left(\mathrm{V}_{10}\right)$. $\mathrm{C}_{\mathrm{V} 10}$, concentration of $\mathrm{V}_{10}$. 
Table 1. The inhibition parameters of the ATPases inhibition by of ammonium $\mathrm{V}_{10}$ obtained by fitting the experimental points by sigmoidal function and Hill analysis

\begin{tabular}{|c|c|c|c|c|c|c|}
\hline & \multicolumn{3}{|c|}{ Sigmoidal fitting } & \multicolumn{3}{|c|}{ Hill analysis } \\
\hline & $A_{1}$ & $A_{2}$ & $p$ & $\begin{array}{c}\mathrm{IC}_{50}\left(x_{0}\right) \\
(\mathrm{mol} / \mathrm{l})\end{array}$ & $n$ & $\begin{array}{l}\mathrm{IC}_{50} \\
(\mathrm{~mol} / \mathrm{l})\end{array}$ \\
\hline $\mathrm{Na}^{+} / \mathrm{K}^{+}$-ATPase & 99.11 & -0.08 & $0.75 \pm 0.14$ & $(4.74 \pm 1.15) \times 10^{-7}$ & $0.81 \pm 0.13$ & $4.79 \times 10^{-7}$ \\
\hline $\mathrm{Ca}^{2+}$-ATPase & 104.59 & 6.41 & $0.44 \pm 0.11$ & $(3.13 \pm 1.70) \times 10^{-8}$ & $0.46 \pm 0.05$ & $4.68 \times 10^{-8}$ \\
\hline $\mathrm{Mg}^{2+}$-ATPase & 99.61 & 10.85 & $1.55 \pm 0.33$ & $(1.05 \pm 0.10) \times 10^{-4}$ & $1.08 \pm 0.11$ & $1.58 \times 10^{-4}$ \\
\hline $\begin{array}{l}\text { Commercial } \\
\mathrm{Na}^{+} / \mathrm{K}^{+} \text {-ATPase }\end{array}$ & 101.99 & 7.94 & $0.94 \pm 0.06$ & $(1.30 \pm 0.10) \times 10^{-6}$ & $0.88 \pm 0.03$ & $1.71 \times 10^{-6}$ \\
\hline
\end{tabular}

$A_{1}, A_{2}, p$ - parameters of sigmoidal function; $\mathrm{IC}_{50}$, half-maximum inhibitory concentration of the enzyme activity; $\mathrm{IC}_{50}\left(x_{0}\right), \mathrm{IC}_{50}$ determined by sigmoidal fitting; $n$, Hill's coefficiet.

observed at several orders of magnitude higher concentration of $\mathrm{V}_{10}$ : $(1.05 \pm 0.10) \times 10^{-4} \mathrm{~mol} / \mathrm{l}$.

\section{Kinetic analysis}

To evaluate the nature of the P-type ATPases inhibition by $\mathrm{V}_{10}$, the kinetic parameters of commercial porcine cerebral cortex $\mathrm{Na}^{+} / \mathrm{K}^{+}$-ATPase, $\mathrm{K}_{\mathrm{m}}$ and $\mathrm{V}_{\text {max }}$, were determined by varying the concentration of $\mathrm{MgATP}^{2-}$. The kinetic properties of the enzyme were determined in the absence and presence of $\mathrm{IC}_{50}$ of $\mathrm{V}_{10}\left(1.30 \times 10^{-6} \mathrm{~mol} / \mathrm{l}\right)$. The dependence of the initial reaction rate $v s$. substrate concentration in the presence and absence of inhibitor exhibited typical Michaelis-Menten kinetics, and is presented in Fig. 4. Ki-

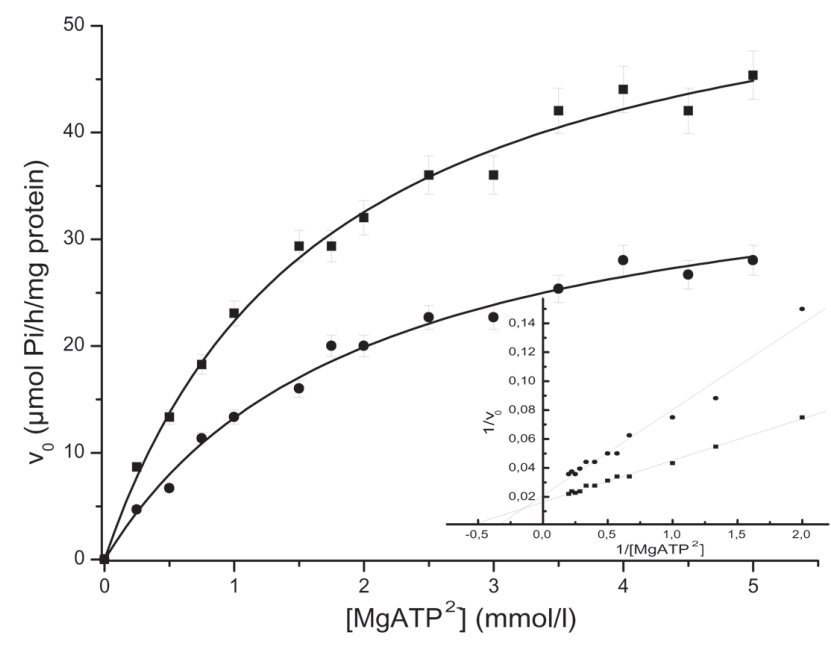

Figure 4. $\mathrm{Na}^{+} / \mathrm{K}^{+}$-ATPase specific activity (expressed as initial velocity $\mathrm{v}_{0}$ ) dependence on $\mathrm{MgATP}^{2-}$ in the absence (square) and presence (circle) of $1 \times 10^{-6} \mathrm{~mol} / 1 \mathrm{~V}_{10}$. The experimental conditions are described in Materials and Methods. The values (expressed as $\mu$ mol released inorganic phosphate $(\mathrm{Pi})$ ) given are the mean of at least three experiments \pm S.E.M., conducted in duplicate. The Lineweaver-Burk transformation of the data is shown in the inset. netic constants were calculated from the experimental data by nonlinear regression fitting (hyperbola function) as well as Lineweaver-Burk transformation (Fig. 4, inset), and are summarized in Table $2 . \mathrm{K}_{\mathrm{m}}$ and $\mathrm{V}_{\max }$ values obtained by nonlinear regression fitting are in good agreement with values obtained by linear fitting model. As can be seen, $V_{10}$ induced mixed type of inhibition of $\mathrm{Na}^{+} / \mathrm{K}^{+}$-ATPase activity by significant decreasing its maximal velocity ( $\mathrm{V}_{\max }$ value), as well as decreasing its apparent affinity for ATP (increased $\mathrm{K}_{\mathrm{m}}$ value).

\section{Discussion}

In the present study we investigated the effect of vanadate decamer on the activity of rat synaptosomal plasma membrane ATPases. Vanadium solution contains different oligomeric $(n=1-10)$ vanadate species in equilibrium, e.g., monomeric, dimeric, tetrameric and decameric and, with different states of protonation and conformation, depending of the $\mathrm{pH}$ (Tiago et al. 2004). The acidification from $\mathrm{pH} 7$ to $\mathrm{pH} 5$ leads to the formation of yellow solution containing the $\mathrm{V}_{10}$ core $\left[\mathrm{V}_{10} \mathrm{O}_{28}\right]^{6-}$, which can be found in several protonation states $\left[\mathrm{H}_{2} \mathrm{~V}_{10} \mathrm{O}_{28}\right]^{4-}\left[\mathrm{H}_{3} \mathrm{~V}_{10} \mathrm{O}_{28}\right]^{3-}$ and $\left[\mathrm{H}_{4} \mathrm{~V}_{10} \mathrm{O}_{28}\right]^{2-}$.

Table 2. Kinetic analysis of commercial porcine cerebral cortex $\mathrm{Na}^{+} / \mathrm{K}^{+}$-ATPase activity in the absence and presence of $\mathrm{V}_{10}(1.30$ $\left.\times 10^{-6} \mathrm{~mol} / \mathrm{l}\right)$

\begin{tabular}{|l|l|l|}
\hline & \multicolumn{1}{|c|}{ Control } & \multicolumn{1}{c|}{$\mathrm{V}_{10}$} \\
\hline \multirow{2}{*}{$\mathrm{K}_{\mathrm{m}}(\mathrm{mmol} / \mathrm{l})$} & $1.68 \pm 0.14^{*}$ & $2.38 \pm 0.20^{*}$ \\
\cline { 2 - 3 } & $1.76 \pm 0.02^{* *}$ & $2.69 \pm 0.09^{* *}$ \\
\hline $\mathrm{V}_{\max }\left(\mu \mathrm{mol} \mathrm{P}_{\mathrm{i}} / \mathrm{h} / \mathrm{mg}\right)$ & $59.93 \pm 2.02^{*}$ & $39.65 \pm 1.72^{*}$ \\
\cline { 2 - 3 } & $61.13 \pm 1.75^{* *}$ & $41.87 \pm 1.35^{* *}$ \\
\hline
\end{tabular}

$\mathrm{V}_{10}$, decavanadate; $\mathrm{K}_{\mathrm{m}}$, Michaelis constant; $\mathrm{V}_{\text {max }}$, maximum enzymatic velocity; $\mathrm{Pi}$, inorganic phosphate; ${ }^{*}$ values obtained by Lineweaver-Burk transformation; ${ }^{* *}$ values obtained by nonlinear regression fitting-hyperbola function. 
In this kind of compound, the location of the protons is important because of the basic role played by the oxygen sites in the reactivity of the polyanion. Obtained IR spectra of the synthesized vanadate decamer (Fig. 2) exhibits bands with position characteristic for non-protonated $\mathrm{V}_{10}$ anion.

The obtained results (Table 1 and Fig. 3) show that $\mathrm{V}_{10}$ exhibits concentration-dependent inhibitory effect on the activity of all investigated enzymes. These results are in agreement with previously reported findings that $\mathrm{V}_{10}$ oxoanion inhibits several nucleotide-dependent enzymes (Boyd et al. 1985; Aureliano et al. 2000), although the data about decavanate influence on plasma membrane ATPases are scant.

The sensitivity of investigated ATPases toward vanadate decamer, as shown in our study, is quite different. It is obvious that PMCA is the most sensitive toward $\mathrm{V}_{10}$ anion (Table 1). Moreover, obtained inhibitory parameters for $\mathrm{V}_{10}$ show that PMCA is two orders of magnitude more sensitive than sarcoplasmic reticulum $\mathrm{Ca}^{2+}$-ATPase from rabbit skeletal muscles (Varga et al. 1985). Both SPM and commercial sodium pumps are about one order of magnitude less sensitive than PMCA, while the activity of ecto-ATPase is about thousand times more resistant to $\mathrm{V}_{10}$ anion than investigated P-type ATPases. These results are in agreement with previously reported data, that SPM ecto-ATPase from rat brain is significantly less sensitive toward different metal ions than $\mathrm{Na}^{+} / \mathrm{K}^{+}$-ATPase (Vasić et al. 1999; Krstić et al. 2005).

Kinetic analysis of the results shows that the presence of $\mathrm{V}_{10}$ induces significant decrease in $\mathrm{V}_{\max }$ and increase in $\mathrm{K}_{\mathrm{m}}$ values of $\mathrm{Na}^{+} / \mathrm{K}^{+}$-ATPase (Table 2) related to control. Moreover, different points of intersection of straight lines with $\mathrm{x}$-axis and $\mathrm{y}$-axis obtained from Lineweaver-Burk analysis of the kinetic data in the absence and presence of $\mathrm{V}_{10}$ confirm mixed mode of interaction (Fig. 4 , inset). It indicates that $\mathrm{V}_{10}$ as a reversible mixed inhibitor of $\mathrm{Na}^{+} / \mathrm{K}^{+}$ATPase activity binds to enzyme sites participating in both substrate binding and catalysis. Obtained mixed inhibition is in agreement with previously reported results that there are two binding sites for $\mathrm{V}_{10}$ on $\mathrm{Ca}^{2+}$-ATPase which belongs, as well as $\mathrm{Na}^{+} / \mathrm{K}^{+}$-ATPase, to P-type of ATPases (Varga et al. 1985; Stokes et al. 2005). Decrease in apparent affinity for $\mathrm{MgATP}^{2-}$ is in agreement with competition of $\mathrm{V}_{10}$ with fluorescein isothocyanate for ATP binding site of $\mathrm{Ca}^{2+}$-ATPase (Csermely et al. 1985). Obtained decrease in maximal velocity of the enzyme reaction probably can be explained by binding of $\mathrm{V}_{10}$ to another binding site that is, as earlier reported (Csermely et al. 1985), binding site for inorganic phosphate on $\mathrm{Ca}^{2+}$-ATPase.

It could be summarized that the obtained dose-dependent inhibition of PMCA and sodium pump by $\mathrm{V}_{10}$, as well as kinetic analysis, is in agreement with previously reported findings that decameric vanadate species block the active side of P-type ATPases and consequently affect phosphorylation step in the enzyme cycle of P-type ATPases (sodium and calcium pump) (Stokes et al. 2005). However, this mechanism could not be responsible for obtained ecto-ATPase inhibition (a member of ecto-NTPDases) and probably occurs via different mechanism resulting in less sensitivity compared to P-type ATPases (sodium and calcium pump).

Acknowledgement. Authors would like to thank to the Ministry of Science and Technological Development of the Republic of Serbia for their financial support (project No. 142051).

\section{References}

Aureliano M. (2000): Vanadate oligomer inhibition of passive and active $\mathrm{Ca} 2+$ translocation by the $\mathrm{Ca} 2+$ pump of sarcoplasmic reticulum. J. Inorg. Biochem. 80, 145-147; doi:10.1016/S0162-0134(00)00022-2

Aureliano M., Gândara R. M. C. (2005): Decavanadate effects in biological systems. J. Inorg. Biochem. 99, 979-985; doi:10.1016/j.jinorgbio.2005.02.024

Blasiak J. (1995): Cooperative binding of the organophosphate paraoxon to the $\mathrm{Na}+/ \mathrm{K}+-A T P a s e . Z$. Naturforsch., C 50, 660-663

Boyd D. W., Kustin K., Niwa M. (1985): Do vanadate polyanions inhibit phosphotransferase enzymes? Biochim. Biophys. Acta 827, 472-475

Cantley L. C., Josephson L., Warner R., Yanacisawa M., Lechene C., Guidotti G. (1977): Vanadate is a potent (Na, K)-ATPase inhibitor found in ATP derived from muscle. J. Biol. Chem. 252, 7421-7423

Chinea B., Dakternieks D., Duthie A., Ghilardi C. A., Gili P., Mederos A., Midollini S., Orlandini A. (2000): Synthesis and characterization of $\left(\mathrm{NH}_{4}\right)_{4}\left[\mathrm{H}_{4} \mathrm{~V}_{10} \mathrm{O}_{28}\right]\left[\mathrm{NTPH}_{2}\right]_{2} \cdot 4 \mathrm{H}_{2} \mathrm{O}$ $\left(\mathrm{NTPH}_{3}=\mathrm{N}\left(\mathrm{CH}_{2} \mathrm{CH}_{2} \mathrm{COOH}\right)_{3}\right)$. Inorg. Chim. Acta 298, 172-177; doi:10.1016/S0020-1693(99)00440-5

Cohen R. S., Blomberg F., Berzins K., Siekevitz P. (1977): The structure of postsynaptic densities isolated from dog cerebral cortex: I. overall morphology and protein composition. J. Cell Biol. 74, 181-203; doi:10.1083/jcb.74.1.181

Csermely P., Varga S., Martonosi A. (1985): Competition between decavanadate and fluorescein isothiocyanate on the $\mathrm{Ca} 2+-$ ATPase of sarcoplasmic reticulum. Eur. J. Biochem. 150, 455-460; doi:10.1111/j.1432-1033.1985.tb09043.x

D’Cruz O. J., Dong Y., Uckun F. M. (2003): Potent dual anti-HIV and spermicidal activities of novel oxovanadium (V) complexes with thiourea non-nucleoside inhibitors of HIV-1 reverse transcriptase. Biochem. Biophys. Res. Commun. 302, 253-264; doi:10.1016/S0006-291X(03)00161-X

Escobar E., Baran E. J. (1981): The vibration spectra of some crystalline decavanadate. Monatsh. Chem. 112, 43-49 (in German); doi:10.1007/BF00906241

Heinemann G., Fichtl B., Vogt W. (2003): Pharmacokinetics of vanadium in humans after intravenous administration of a vanadium containing albumin solution. Br. J. Clin. Pharmacol. 55, 241-245; doi:10.1046/j.13652125.2003.01711.x 
Horvat A., Orlić T., Banjac A., Momić T., Petrović S., Demajo M. (2006): Inhibition of rat brain ecto-ATPase activity by various drugs. Gen. Physiol. Biophys. 25, 91-105

Kanna P. S., Mahendrakumar C. B., Indira B. N., Srivastawa S., Kalaiselvi K., Elayaraja T., Chatterjee M. (2004): Chemopreventive effects of vanadium toward 1,2-dimethylhydrazine-induced genotoxicity and preneoplastic lesions in rat colon. Environ. Mol. Mutagen. 44, 113-118; doi:10.1002/em.20038

Krstić D., Krinulović K., Spasojević-Tišma V., Joksić G., Momić T., Vasić V. (2004): Effects of digoxin and gitoxin on the enzymatic activity and kinetic parameters of $\mathrm{Na}+/ \mathrm{K}+-$ ATPase. J. Enzyme Inhib. Med. Chem. 19, 409-415; doi:10.1080/14756360410001722065

Krstić D., Krinulović K., Vasić V. (2005): Inhibition of Na+/K+ATPase and Mg2+-ATPase by metal ions and prevention and recovery of inhibited activities by chelators. J. Enzyme Inhib. Med. Chem. 20, 469-476; doi:10.1080/ 14756360500213280

Lefranc F., Mijatović T., Kondo Y., Sauvage S., Roland I., Krstić D., Vasić V., Gailly P., Kondo S., Blanco G., Kiss R. (2008): Targeting the al subunit of the sodium pump to combat glioblastoma cells. Neurosurgery 62, 211-222; doi:10.1227/01.NEU.0000311080.43024.0E

Messmore J. M., Raines R. T. (2000): Decavanadate inhibits catalysis by ribonuclease A. Arch. Biochem. Biophys. 381, 25-30; doi:10.1006/abbi.2000.1951

Molinuevo M. S., Barrio D. A., Cortizo A. M., Etcheverry S. B. (2004): Antitumoral properties of two new vanadyl(IV) complexes in osteoblasts in culture: role of apoptosis and oxidative stress. Cancer Chemother. Pharmacol. 53, 163-172; doi:10.1007/s00280-003-0708-7

Nagy A. (1986): Enzymatic characteristics and possible role of synaptosomal ecto-ATPases from mammalian brain. In: Cellular Biology of Ecto-Enzymes. (Eds. G. W. Kreutzberg, M. Reddington and H. Zimmermann), pp. 49-59, Springer-Verlag, Heidelberg-Berlin-New York-Tokyo

Nikezić G., Horvat A., Nedeljković N., Todorović S., Nikolić V., Kanazir D., Vujisić Lj., Kopečni M. (1998): Influence of pyridine and urea on the rat brain ATPase activity. Gen. Physiol. Biophys. 17, 15-23

Perrella F. W. (1988): EZ-FIT: a practical curve-fitting microcomputer program for the analysis of enzyme kinetic data on IBM-PC compatible computers. Anal. Biochem. 174, 437-447; doi:10.1016/0003-2697(88)90042-5

Pezza R. J., Villarreal M. A., Montich G. G., Argarana C. E. (2002): Vanadate inhibits the ATPase activity and DNA binding capability of bacterial MutS. A structural model for the vanadate-MutS interaction at the Walker A motif. Nucleic Acids Res. 30, 4700-4708; doi:10.1093/nar/gkf606
Phillips T. D., Hayes A. W., Ho I. K., Desaiah D. (1978): Effects of rubrotoxin $\mathrm{B}$ on the kinetics of cationic and substrate activation of $\mathrm{Na}+, \mathrm{K}+$-ATPase and p-nitrophenyl phosphatase. J. Biol. Chem. 253, 3487-3493

Rodriguez de Lores Arnaiz G., Pena C. (1995): Characterization of synaptosomal membrane $\mathrm{Na}+\mathrm{K}+$-ATPase inhibitors. Neurochem. Int. 27, 319-327; doi:10.1016/01970186(95)00013-X

Sakurai H., Inohara T., Adachi Y., Kawabe K., Yasui H., Takada J. (2004): A new candidate for insulinomimetic vanadium complex: synergism of oxovanadium(IV)porphyrin and sodium ascorbate. Bioorg. Med. Chem. Lett. 14, 1093-1096; doi:10.1016/j.bmcl.2003.12.081

Scheiner-Bobis G. (2002): The sodium pump; its molecular properties and mechanics of ion transport. Eur. J. Biochem. 269, 2424-2433; doi:10.1046/j.1432-1033.2002.02909.x

Stokes D. L., Delavoie F., Rice W. J., Champeil P., McIntosh D. B., Lacapére J. J. (2005): Structural studies of a stabilized phosphoenzyme intermediate of Ca2+-ATPase. J. Biol. Chem. 280, 18063-18072; doi:10.1074/jbc.M500031200

Tiago T., Aureliano M., Gutiérrez-Merino C. (2004): Decavanadate binding to a high affinity site near the myosin catalytic centre inhibits F-actin-stimulated myosin ATPase activity. Biochemistry 43, 5551-5561; doi:10.1021/ bi049910+

Towle A. C., Sze P. Y. (1983): Steroid binding to synaptic plasma membrane: differential binding of glucocorticoid and gonadal steroids. J. Steroid Biochem. 18, 135-143; doi:10.1016/0022-4731(83)90079-1

Varga S., Csermely P., Martonosi A. (1985): The binding of vanadium (V) oligoanions to sarcoplasmic reticulum. Eur. J. Biochem. 148, 119-126; doi:10.1111/j.1432-1033.1985. tb08815.x

Vasić V., Jovanović D., Krstić D., Nikezić G., Horvat A., Vujisić Lj., Nedeljković N. (1999): Prevention and recovery of CuSO4 induced inhibition of $\mathrm{Na}+/ \mathrm{K}+$-ATPase and $\mathrm{Mg} 2+$-ATPase in rat brain synaptosomes by EDTA. Toxicol. Lett. 110, 95-104; doi:10.1016/S0378-4274(99)00144-7

Vasilets L. A., Schwarz W. (1993): Structure-function relationships of cation binding in $\mathrm{Na}+/ \mathrm{K}+-\mathrm{ATP}$ ase. Biochim. Biophys. Acta. 1154, 201-222

Yang X. G., Yang X. D., Yuan L., Wang K., Crans D. C. (2004): The permeability and cytotoxicity of insulin-mimetic vanadium compounds. Pharm. Res. 21, 1026-1033; doi:10.1023/B:PHAM.0000029293.89113.d5

Zylinska L., Soszynski M. (2000): Plasma membrane Ca2+-ATPase in excitable and nonexcitable cells. Acta Biochim. Pol. 47, 529-539

Received: October 24, 2008

Finnal version accepted: February 13, 2009 